\title{
Titae
}

35 (2019) 477-503

Krzysztof Pawlina

Papieski Wydział Teologiczny w Warszawie, Collegium Joanneum

kpawlina@wmsd.mkw.pl, ORCID: 0000-0002-3855-6720

\section{PoKOlENIE POLSKICH MILENIALSÓW. STUDIUM SOCJOLOGICZNO-PASTORALNE}

\section{Polish Millennials Generation. Socio-Pastoral Study}

Generacja młodych Polaków, jak nigdy dotąd, młodzież, przeżywa duże przeobrażenia w sferze religijnej, kulturowej i obyczajowej. Choć określają się oni pokolenie $\mathrm{Y}$, milenialsi, jako osoby wierzące, nie potwierdza się to w ich teologia pastoralna, deklaracjach dotyczących praktyk religijnych ani życia moralnego. Wyczuwa się spore napięcie między wymaganiami stawianymi przez Kościół a pragnieniem wolności. Wolność staje się wartością absolutną, zaś kryterium wartościowania są: zachcianka, użyteczność i ulotność chwili. Mimo że jako swoje cele życiowe wskazują rodzinę, odwzajemnioną miłość i bezpieczeństwo, to jednak w praktyce poszerza się grono ludzi żyjących bez jakiegokolwiek związ$\mathrm{ku}$, a na pewno bez sakramentu małżeństwa. Obniża się wpływ Kościoła na życie młodych Polaków i pomniejsza się wychowawcza rola rodziny. Rodzice wobec swoich dzieci często są bezradni, wielu nawet nie próbuje ich przywartości, badania statystyczne, młodzi Polacy, religijność młodzieży 
naglać do chodzenia na lekcje religii czy do kościoła. Za cenę zachowania relacji ze swoimi dziećmi milczeniem pomijają kwestie moralności i religijności. Młodzi ludzie przełomu wieków odznaczają się dużym poczuciem pewności siebie, są dobrze wykształceni, znają języki obce, czują się obywatelami świata.

Like never before, the present generation of young Poles is undergoing religious, cultural and lifestyle changes. Even though these youngsters describe themselves as believers, this is not demonstrated in either their religious practices nor in their moral lives. There is a visible tension between the expectations of the Church and the current urge for personal freedom, a freedom that is defined by the meeting of individual needs, pragmatism, and the transience of the moment. Although young people claim that family, love and security are their ultimate goals, in practice the number of people living without traditional notions of commitment - particularly living together outside of marriage - is growing. The Church has a decreasing influence on the lives of the youth, and the educational role of the family is diminishing, such that parents are very often helpless in guiding their children. Many adults do not even try to convince their offspring to attend religion classes, or to go to church at all. For fear of losing a good relationship with their children, parents frequently decide to remain silent on topics concerning morality or religion. Much more than in the past, Polish young people are self-confident, well-educated, speak foreign languages, and present themselves as citizens of the world.

young people, generation $\mathrm{Y}$, millennials, pastoral theology, values, statistics, young Poles, religiosity of young people 
Nie ma dziś jednoznacznej opinii o młodzieży. Jedni widzą w niej samo dobro, nadzieję i piękno, drudzy młodych krytykują, obwiniają, a niekiedy wręcz z rezygnacją machają na nich ręką. Jaka jest zatem polska młodzież?

Młodzi ludzie sami dobrze nie wiedzą, jacy są. Dlatego też niełatwo o nich mówić czy ich oceniać. Może jednak warto spróbować naszkicować ich portret? Portret bowiem ma to do siebie, że w dynamicznych procesach chwyta konkretny moment życia, daną chwilę, odzwierciedla rzeczywistość tak, jak ona teraz wygląda. W tym przypadku owo „teraz" uchwycone zostało okiem socjologa.

Dokument końcowy Synodu Biskupów Mtodzi, wiara i rozeznawanie powotania określa we wstępie ogólny paradygmat działania Jezusa wobec swoich uczniów. Paradygmat ten wyjaśniony zostaje na podstawie sceny dialogu Jezusa z uczniami zmierzającymi do Emaus. Uczniowie nie rozumieją obecnego etapu swojej historii, pełni są pytań, wątpliwości, chęci ucieczki do znanego sobie świata. Jezus na początku rozmowy nie burzy ich sposobu myślenia, ale cierpliwie słucha, starając się zrozumieć ich wnętrze. „Aby być $\mathrm{w}$ ich towarzystwie, przebywa $\mathrm{z}$ nimi drogę. Zadaje im pytania i cierpliwie słucha ich wersji faktów, aby pomóc im rozpoznać to, co przeżywają" ${ }^{1}$. Dokument postuluje, aby ten sam model wychowania do wiary i do życia społecznego stosować w relacji ze współczesną młodzieżą.

Początkiem duszpasterstwa jest więc słuchanie, wręcz wsłuchiwanie się w głos drugiego człowieka. Celem niniejszego artykułu jest przede wszystkim syntetyczna prezentacja socjologicznych badań polskiej młodzieży. Jest to rodzaj wsłuchiwania się w jej obecny stan ducha, w jej poglądy i aspiracje. Dzięki temu możliwe jest budowanie duszpasterstwa skutecznie adresowanego do konkretnych osób i grup, do wspólnot akademickich i młodzieżowych, do uczniów biorących udział w katechezie.

1 Synod Biskupów, Mtodzi, 6. 
Trzeci rozdział drugiej części wspomnianego wyżej dokumentu postuluje „towarzyszenie integralne”, w które zaangażowane są - oprócz rodziny - inne osoby: nauczyciele, wychowawcy, trenerzy, duchowni ${ }^{2}$. Każda z tych kategorii wychowawców troszczy się o właściwy jej obszar wzrastania. Kościół - według zamysłu ojców synodalnych - powinien towarzyszyć uczniom nie tylko na drodze wiary, lecz także w podejmowaniu odpowiedzialności społecznej za życie rodzinne, zawodowe i polityczne, a także w odkrywaniu przez nich swojej tożsamości i w przezwyciężaniu pokusy relatywizmu życia. W tym właśnie kluczu zostały dobrane wyniki badań socjologicznych. Ich celem jest nakreślenie czyli wysłuchanie - głosu młodzieży w priorytetowych obszarach wychowania do wiary i do życia w społeczeństwie.

Mówiąc "młodzież”, warto uściślić, o jaką grupę młodych ludzi dokładnie chodzi. Przedmiotem poniższej pracy będzie generacja polskich milenialsów, zwanych również pokoleniem Y. Trudno jest jednak określić sztywne ramy wyznaczające przedział czasowy, w którym urodzili się przedstawiciele tej generacji ${ }^{3}$. Na potrzeby niniejszej pracy zakłada się widełki czasowe obejmujące lata 1990-2004.

\section{Dzieci SIECi}

Dorastali z Internetem i w Internecie, pod wpływem wszystkiego co jest „i" albo „e”: iPhone, iPad, iPod, e-maile, e-booki, e-zakupy. Jak trafnie zauważył Janusz Czapiński, ich mentalność kształtowana jest przez memy, a nie przez mamy ${ }^{4}$. Oni są ze świata cyfrowego, ludzie starsi od nich $\mathrm{z}$ analogowego ${ }^{5}$. To pokolenie, wyrosłe w otoczeniu mediów społecznościowych i ogólnie technologii cyfrowych, bywa

\footnotetext{
2 Synod Biskupów, Mtodzi, 36.

3 Pawińska, Millennialsi, 216.

4 SIA, „Czapiński”.

5 Moczyróg, „Było pokolenie Y”.
} 
często określane również jako: digital natives, generacja MTV, pokolenie iPadów, Millenium Kids, net generation, screenagers, iGen, Gen C. ${ }^{6}$

Podczas gdy poprzednie pokolenia swój status musiały sobie dopiero wypracowywać, a niekiedy wręcz wywalczać, generacja Y od razu weszła w życie wyposażona we wszelkiego rodzaju dobra. Zadbali o ten stan rzeczy ich rodzice, zapewniając swoim dzieciom wykształcenie, dobrobyt, finansując wakacje i różne rozrywki ${ }^{7}$.

Milenialsi są pierwszym pokoleniem urodzonym po PRL. Ich cechy będą cechami naszego społeczeństwa. Czym zatem charakteryzuje się ta generacja?

- Pewność siebie. To chyba kluczowe pojęcie wyróżniające pokolenie Y. Od dziecka słyszeli, że są wyjątkowi. Byli wychowywani w przeświadczeniu o swojej skuteczności, sprawczości, o własnych zdolnościach i kompetencjach ${ }^{8}$.

- Niecierpliwość. Funkcjonują w rzeczywistości opartej na filozofii „mówisz - masz”. Wszak dziś, żeby zapisać się do szkoły, zamówić lot albo miejsce w kinie, zrobić zakupy, a nawet znaleźć partnera, wystarczy tylko kliknąć w odpowiednie pole?.

- Brak umiejętności skupienia się przez dłuższy czas na jednej rzeczy. Młodzi odczuwają irytację, gdy określona czynność lub zjawisko zanadto się przedłuża. Monotonia jest dla nich nie do zniesienia ${ }^{10}$.

- Życie online. Posiadanie konta na portalu społecznościowym jest dla nastolatków zjawiskiem powszechnym. Ma je 95\% uczniów szkół gimnazjalnych i ponadgimnazjalnych ${ }^{11}$. Przeciętny milenials posiada ich kilka, wie zatem, jak kreować swój wizerunek i ciągle ocenia wizerunki in-

\footnotetext{
6 Flader, „Wiara”, 439.

7 Polityka.pl, „Milenialsi”.

8 Polityka.pl, „Milenialsi”.

9 Pawińska, Millennialsi, 217.

10 Pawińska, Millennialsi, 217.

11 Raport z badania Nastolatki 3.0, 53.
} 
nych $^{12}$. Sieć jest ich domem: Twitter zastąpił codzienną prasę, Facebook stał się centrum życia towarzyskiego, a Instagram to świetne miejsce na wrzucanie selfie i dbanie o swój image.

- Otwartość i kreatywność. Cechy te intensywniej ujawniają się w świecie cyfrowym niż realnym, gdyż milenialsi bardziej funkcjonują we wspólnotach wirtualnych.

- Używanie zamiast posiadania. To najbardziej rewolucyjna cecha tego pokolenia. Dotychczas znakomita większość społeczeństwa starała się dorobić własnego auta czy mieszkania. Milenialsi chcą tylko używać. Nie widzą potrzeby kupowania - wolą wynająć lub wziąć w leasing.

- Potrzeba uspołeczniania. Nie przywiązują się do struktur ani rzeczy. Używają firmy do realizacji swoich idei. Dla starszego pokolenia firma była wartością samą w sobie. Mówiło się z dumą: mam firmę! Milenialsi mówią: mam pomyst!

- Brak szacunku dla autorytetów i hierarchii. Milenialsi traktują wszystkich partnersko, niezależnie od stanowiska lub wieku. Nie chcą słuchać ekspertów, bo sami chcą być ekspertami. To zwolennicy współpracy o charakterze egalitarnym, a nie hierarchicznym ${ }^{13}$. Lubią działać kolektywnie i kolektywnie myśleć. W takim kolektywie nie ma miejsca dla uprzywilejowanych. Nikt nie jest ważniejszy tylko dlatego, że jest prezesem, biskupem czy redaktorem naczelnym. Nie obchodzi ich, jaki masz tytut - oni chcą wiedzieć, co sobą reprezentujesz ${ }^{14}$.

- Trudność w kontaktach $\mathrm{z}$ ludźmi w świecie realnym. W porównaniu z przedstawicielami wcześniejszych pokoleń dużo trudniejsze są dla nich prowadzenie tradycyjnej konwersacji i chwile ciszy zapadające w trakcie takiej rozmowy. Mają problem z prowadzeniem towarzyskiej

\footnotetext{
12 Pawińska, Millennialsi, 219.

13 Pawińska, Millennialsi, 218.

14 Espinoza Ukleja, Zarządzanie milenialsami, 40.
} 
pogawędki w realnym życiu. Bywa, że czując się niezręcznie w trakcie rozmowy, chwytają za telefon, by dać sobie pretekst do uniknięcia kontaktu powodującego skrępowanie ${ }^{15}$.

Ponadto młodzi z pokolenia Y nie potrzebują tak wiele społecznej akceptacji jak ich poprzednicy. Uważają, że w dobie Internetu każdy może znaleźć swoją niszę i poczuć się „na swoim miejscu”. O sobie mówią: „tak jak kiedyś konieczna była emigracja wewnętrzna, tak my wybraliśmy emigrację cyfrową. I choć nie ma dla nas niekiedy miejsca w mainstreamie, to jesteśmy dziećmi sieci. Żyjemy w sieci to jest jedyne miejsce, które uważamy za nasze" ${ }^{16}$.

\section{System WARtości}

Najbardziej cenione przez młodzież wartości to tradycyjnie: rodzina (94,3\%), zdrowie (92,3\%) i prawdziwa przyjaźń (91,2\%). Na kolejnych miejscach plasują się: kariera zawodowa $(88,8 \%)$, wykształcenie $(88,9 \%)$, wolność głoszenia własnych poglądów (88\%) i szacunek innych ludzi (86,4\%). W trzeciej grupie znalazły się: powodzenie materialne $(78,1 \%)$, małżeństwo $(73,1 \%)$ i ojczyzna $(72,1 \%)^{17}$.

Zastanawia duża rozbieżność między takimi wartościami jak rodzina i małżeństwo. To ostatnie znalazło się dopiero na 9. miejscu na piętnastopunktowej liście ankietowego kwestionariusza. Może to wynikać z faktu, że na tym etapie życia młodzież jeszcze nie myśli o małżeństwie. Potwierdzałyby to dane GUS wskazujące, że obecnie średni wiek mężczyzn i kobiet wchodzących w związki małżeńskie to odpowiednio 29 i 27 lat $^{18}$. Z drugiej strony może to również oznaczać, że małżeństwo nie jest uważane przez młodzież

15 Pawińska, Millennialsi, 220.

16 Czerski, „My, dzieci sieci”, 11.

17 Kaźmierska, Mtodzież archidiecezji tódzkiej, 49.

18 Stańczak - Stelmach - Urbanowicz, Matżeństwa i dzietność w Polsce, 2. 
jako warunek sine qua non życia rodzinnego. Dysproporcja między wyborem rodziny i małżeństwa jako wartości może wynikać także $\mathrm{z}$ wizji jego nietrwałości ${ }^{19}$. W przekonaniu młodych małżeństwo to spółka $\mathrm{z}$ ograniczoną odpowiedzialnością. Kiedy upada, zawiera się drugie. Potwierdzają to najnowsze badania ujawniające wzrastającą liberalizację postaw w stosunku do instytucji małżeństwa. Małżeństwo jawi się w wyobrażeniach młodzieży jako instytucja mięk$\mathrm{ka}$, bardziej dostosowująca się do indywidualnych potrzeb i oczekiwań partnerów niż do społecznych funkcji i potrzeb. Związek powstaje z potrzeby serca. Ustaje, gdy serce ma inne potrzeby.

W grupie wartości oscylujących na poziomie $60 \%$ wskazań wymieniane są takie wartości jak: życie pełne przygód i wrażeń $(66,5 \%)$, pomaganie innym $(62,6 \%)$ i wiara $(60,5 \%)^{20}$. Niepokoić może niska pozycja wiary, zważywszy że odsetek młodzieży deklarującej się jako wierząca jest nadal stosunkowo wysoki $(70 \%)^{21}$.

Mniej cenioną wartością (poniżej 50\%) jest możliwość udziału w demokratycznym życiu społeczno-politycznym (44,3\%), co wskazuje na swoisty dla polskiego społeczeństwa niski stopień zaangażowania obywatelskiego. Ponad $30 \%$ badanych ma obojętny stosunek lub dystansuje się do bezinteresownych działań na rzecz innych, np. do wolontariatu. Według badań CBOS z 2016 r. dotyczących dobroczynności w Polsce wśród osób w wieku 18-24 lata 34\% nie świadczyło żadnej pomocy ${ }^{22}$. Oznacza to, że młodzież nie rekompensuje braku możliwości przeznaczenia środków pieniężnych czy rzeczowych wkładem pracy własnej ${ }^{23}$.

\footnotetext{
19 Kaźmierska, Mtodzież archidiecezji tódzkiej, 51-52.

20 Kaźmierska, Mtodzież archidiecezji tódzkiej, 53.

21 Głowacki, „Religijność młodzieży”, 143-153.

22 Boguszewski, „Dobroczynność w Polsce”, 4.

23 Kaźmierska, Mtodzież archidiecezji tódzkiej, 55.
} 
Najniższe wskazania $\mathrm{w}$ kategorii wartości ma sława $(14,8 \%)$, co z kolei może świadczyć o tym, że młodym nie zależy na tzw. celebryctwie ${ }^{24}$.

Głównym źródłem poszukiwania wartości są rodzina i przyjaciele (nieutożsamiani z grupą rówieśniczą). Mimo deklaracji wiary religia dla zdecydowanej większości $(77,4 \%)$ nie jest źródłem wartości, co wskazuje na niespójność między wartościami deklarowanymi, wyznawanymi i praktykowanymi ${ }^{25}$.

W percepcji młodzieży o tym, że coś jest wartością albo nią nie jest, nie decyduje już obiektywna prawda, ale to, w jaki sposób to coś zostało przedstawione. Jeśli jest użyteczne, przydatne, to przyjmuje się to jako wartość.

$\mathrm{Z}$ systemem wyznawanych wartości wiąże się kwestia ewentualnych autorytetów. Jak już wcześniej wspomniano, młodych nie interesują stanowiska, pozycje czy tytuły, ale to, co dana osoba sobą reprezentuje. Maturzyści rocznik 2018 jednego $\mathrm{z}$ warszawskich liceów zapytani o swoje autorytety wskazali na znanych zagranicznych naukowców i ludzi biznesu. Podsumowali swój wybór tak: „Z naszych wypowiedzi wynika, że autorytetem zostaje ten, kto odniósł sukces, zdobył popularność i pieniądze" ${ }^{\text {"26 }}$. Następnie dodali: „Większość ludzi w naszej szkole nie ma jednoznacznego autorytetu albo ideologii, którą by wyznawali (...) Poza tym Polska jest podzielona, więc nie ma autorytetów wspólnych dla wszystkich, dla ludzi z naszego pokolenia też" ${ }^{27}$.

\section{Cele ŻyCiOWe MŁODZIEŻY}

Pomimo różnorodnych zmian w naszym kraju, dążenia młodzieży pozostają prawie ciągle te same. Ich lista kształ-

\footnotetext{
24 Kaźmierska, Mtodzież archidiecezji tódzkiej, 53.

25 Kaźmierska, Mtodzież archidiecezji tódzkiej, 64-65.

26 Tomczuk, „Pokolenie «lap szansę»”, 33.

27 Tomczuk, „Pokolenie «lap szansę»”, 33.
} 
tuje się od wielu lat bardzo podobnie. Najważniejsze dla młodych ludzi pozostają niezmiennie miłość i przyjaźń (48\%) oraz udane życie rodzinne (42\%). Na kolejnym miejscu znalazł się zawodowy wymiar egzystencji: dwie piąte badanych (40\%) jako cel wyznacza sobie zdobycie ciekawej pracy - zgodnie z zainteresowaniami, a jedna trzecia (34\%) aspiruje do osiągnięcia wysokiej pozycji zawodowej. Innym ważnym celem życiowym uczniów są satysfakcjonująca sytuacja materialna (28\%) oraz spokojne życie, bez kłopotów i konfliktów $(27 \%)^{28}$.

Jeśli chodzi o ambicje edukacyjne, to niemal trzy piąte (57\%) planuje podjąć studia. Połowa z nich chciałaby połączyć studia z pracą. Szczególnie preferowane obszary, w których uczniowie chcieliby podjąć studia, to nauki społeczne $(27 \%)$ oraz techniczne (22\%). W trzeciej kolejności wskazali nauki medyczne o zdrowiu i kulturze fizycznej $(15 \%)^{29}$. Wykształcenie stanowi klucz do trzech bardzo ważnych obszarów egzystencji i trzech rodzajów potrzeb: bezpieczeństwa, poziomu i jakości życia oraz prestiżu. Jednak wykształcenie, dotychczas bardzo wysoko cenione przez młodzież, ostatnio zaczyna tracić na znaczeniu. Mimo że zwiększa szanse na lepszy los, nie gwarantuje sukcesu. Część młodzieży zaczyna dostrzegać nieopłacalność zbyt ambitnych edukacyjnych pomysłów. Iluzoryczność dyplomu, oferta kształcenia nieodpowiadająca potrzebom rynku pracy, zjawisko bezrobocia wśród absolwentów szkół wyższych, trud i koszty kształcenia - wszystko to wpływa na zmiany preferencji edukacyjnych. Zauważa się więc „schłodzenie” poziomu aspiracji edukacyjnych. Wzrasta natomiast zainteresowanie kształceniem zawodowym, krótszym i niewymagającym zbyt dużej inwestycji ${ }^{30}$.

\footnotetext{
28 Boguszewski, „Aspiracje”, 65-87.

29 Boguszewski, „Aspiracje”, 65-87.

30 Pawlina, Mtodzież szkolna, 37-39.
} 


\section{WIARA PRZYGODĄ Z SAMYM SOBĄ}

Wiara nie jawi się młodym jako coś potrzebnego do życia. To nie jest rzecz praktyczna, potrzebna na dziś. 40\% tego pokolenia nie chodzi do kościoła, a ci, którzy chodzą, bywają tam dużo rzadziej niż ich rówieśnicy z przeszłości ${ }^{31}$.

W ich postrzeganiu istnieje duże napięcie pomiędzy przykazaniami Bożymi i kościelnymi a wolnością. Mówią: „nikt nie może mi czegokolwiek narzucać, ja mam prawo wybierać i decydować”, „nikt nie ma monopolu na prawdę”. W sprawach moralnych kierują się zasadą: „bo lubię”, „bo jest to wygodne dla mnie”, „bo mi się to przyda w życiu”.

Współczesne pojmowanie wiary i chrześcijaństwa określa się niekiedy jako bufet style: wyłóż mi wszystko na stole, a ja sobie wybiorę to, co mi smakuje ${ }^{32}$.

Obecnie przybiera na sile proces nie tyle selektywnego podejścia do wiary, ile samodzielnego komponowania swojej wiary. W hipermarkecie klient komponuje własny, niepowtarzalny zestaw towarów, swój własny koszyk produktów - podobnie odbywa się to w dziedzinie ducha. Współczesny człowiek zna wiele religii, tradycji religijnych, szkół duchowości, technik medytacyjnych i modlitewnych. Może więc skomponować z tych elementów unikalną, jedyną w swoim rodzaju duchowość. Spotkanie człowieka, który dokonał identycznego jak ja wyboru, nie stanowi dziś jednak powodu do radości. Oznacza bowiem, że prawdopodobnie moja własna religia jest zbyt mało „moja”, tzn. w niewystarczającym stopniu unikatowa. Proces komponowania jedynej w swoim rodzaju, niepowtarzalnej religii należy więc wówczas zacząć na nowo.

Stają się dziś modne wszelkiego rodzaju ruchy mające na celu zaspokojenie różnych potrzeb jednostki. Można więc powiedzieć, że skomponowana przez współczesnego czło-

31 Głowacki, „Religijność młodzieży”, 143-153.

32 Pawlina, Co stychać u mtodzieży, 41. 
wieka jego własna religia nie oznacza relacji z Bogiem oraz ludźmi, ale jest duchową przygodą z samym sobą.

Zindywidualizowaną religijność częściej niż inni przejawiają osoby nieregularnie i sporadycznie uczestniczące w praktykach religijnych, mające od 25 do 34 lat, mieszkające w dużych, ale nie największych miastach oraz określające swoje poglądy polityczne jako lewicowe lub centrowe ${ }^{33}$.

\section{RELIGIJNOŚĆ I KONDYCJA MORALNA}

Mimo powyższego młodzież całkowicie nie odrzuca religii. Wszelkiego rodzaju badania, zarówno ogólnopolskie, jak i lokalne pokazują, że religia jest w życiu człowiekowi potrzebna. Według tych badań religia pełni wiele funkcji, na przykład funkcję sensotwórczą czy terapeutyczną. Stąd zdecydowana większość młodzieży deklaruje się jako wierząca. Jednak jest to wiara subiektywna, selektywna lub wiara wątpiąca. Młodzi mówią na przykład: „wierzę w Boga, ale nie wierzę w piekło”; „wierzę w Boga, ale wątpię, że Chrystus był Bogiem"34.

Jeśli chodzi o dziedzinę życia moralnego, młode pokolenie niechętnie przyjmuje głoszone przez Kościół zasady, szczególnie te dotyczące moralności małżeńskiej i rodzinnej, a zwłaszcza zasad odnoszących się do życia seksualnego. Na ogół akceptowana jest norma nakazująca wierność małżeńską, w mniejszym stopniu norma stojąca na straży życia nienarodzonych. W wyraźnym kryzysie są normy związane z nierozerwalnością małżeństwa, z czystością przedmałżeńską i regulacją poczęć. Można pokusić się o stwierdzenie, że w XXI wieku mamy do czynienia w środowiskach młodzieżowych nie tyle $\mathrm{z}$ wahaniami opinii, ile raczej z wyraźną zmianą kierunkową w świadomości moralnej. Odchy-

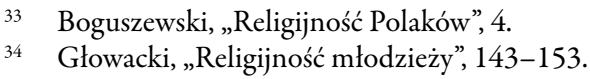


lenia od tradycyjnej moralności seksualnej są tak znaczne, że można mówić o swoistej rewolucji obyczajowej, a nawet moralnej ${ }^{35}$.

Młodzi ludzie czują się bardziej kreatorami niż adresatami norm moralnych. W swoim zachowaniu kierują się często zasadą „bo lubię”, „bo jest dla mnie wygodnie”. Zasadniczo w sprawach moralnych młodzi nie akceptują jakiejkolwiek ingerencji osób trzecich. „Nikt mi nie będzie dyktował, co mam robić" - mówią.

Cechą młodego pokolenia jest też sytuacjonizm. Polega on na tym, że młodzi pytani o ocenę moralną, odpowiadają: „to zależy od sytuacji”. Nie ma więc czegoś stałego. Wszystko jest uzależnione od czegoś.

Wyniki ankiet wskazują na mniejsze religijne zaangażowanie młodych ludzi, a przynajmniej przeobrażanie się jego charakteru. Spada odsetek uczniów określających się jako wierzący, coraz rzadsze jest także uczestnictwo młodzieży w praktykach religijnych. Obecnie nieco powyżej dwóch trzecich uczniów ostatnich klas ponadgimnazjalnych (69\%) uważa się za osoby wierzące, w tym $9 \%$ - za głęboko wierzące. Prawie jedna piąta (18\%) określa swoją postawę wiary religijnej jako niezdecydowanie, a co ósmy badany (13\%) deklaruje brak wiary ${ }^{36}$.

Od połowy lat dziewięćdziesiątych odsetek wierzących wśród młodzieży spada. W 1996 r. jako wierzący deklarowało się $80 \%$ młodych ludzi, w tym 6\% jako głęboko wierzący. W 2003 roku - 78\% wierzących, w tym 8\% głęboko wierzących. Podobną tendencję zaobserwowano w 2013 roku $-71 \%$ wierzących, w tym 6\% głęboko wierzących ${ }^{37}$.

Pojawil się jeszcze inny trend: wzrost liczebności młodzieży niezdecydowanej. W 1996 roku niezdecydowanych było $14 \%$, a w 2016 roku $-18 \%{ }^{38}$.

35 Mariański, „Kondycja religijna”, 146.

36 Głowacki, „Religijność młodzieży”, 143-153.

37 Głowacki, „Religijność młodzieży”, 143-153.

38 Głowacki, „Religijność młodzieży”, 143-153. 
Jako niewierzący w 1996 roku deklarowało się 5\%, a już w 2013 roku - 10\%, zaś w 2016 roku - 13\% ${ }^{39}$.

Zazwyczaj wysokim odsetkiem wiary religijnej wyróżniali się mieszkańcy wsi, dziewczęta, uczniowie techników i szkół zawodowych. Obecne badania socjologiczne ukazują pewną zmianę. Otóż następuje wyrównanie się poziomu religijnego wśród młodych ludzi należących do różnych grup społeczno-demograficznych.

Starając się poznać wiarę młodych, rodzi się pytanie: w co oni tak naprawdę wierzą?

Największa część - około dwóch na pięciu badanych (42\%) - wierzy w Boga i nie ma wątpliwości, co do Jego istnienia. Jedna czwarta (26\%) wprawdzie wierzy w Boga, ale miewa wątpliwości. Blisko co dziesiąty (9\%) twierdzi, że czasem wydaje mu się, że wierzy, a czasem, że nie wierzy w Boga. Podobny odsetek reprezentuje postawę agnostyczną. Najmniejsza grupa badanych uczniów zdecydowanie nie wierzy (8\%) lub wierzy w jakiegoś rodzaju nieosobowe sity wyższe $(7 \%)^{40}$. Te deklaracje nie odbiegają znacząco od wyników z 2013 roku.

\section{Praktyki Religijne}

Jeśli chodzi o praktyki religijne, należy zauważyć nowe zjawisko - religijną spontaniczność. Gdy dzieje się coś wielkiego, młodzi wychodzą z domów: idą na pielgrzymkę, rekolekcje na stadionie albo na koncert religijny. A potem znowu chowają się w swoje życie. Mają trudność z regularnymi praktykami.

Z badań wynika, że 25,3\% młodzieży praktykuje systematycznie; $19 \%$ uczestniczy we mszy świętej w każdą nie-

39 Głowacki, „Religijność młodzieży”, 143-153.

40 Głowacki, „Religijność młodzieży”, 143-153. 
dzielę, $68,8 \%$ spowiada się przynajmniej raz w roku; $20 \%$ deklaruje codzienną modlitwę ${ }^{41}$.

Zasadniczo istnieje wyraźny związek między deklarowaną postawą wobec wiary a udziałem w praktykach religijnych. Osoby praktykujące określają się też częściej jako wierzące. Pojawiło się jednak pewne zjawisko, które można określić mianem „wiary bez praktyki”. Są bowiem osoby, które deklarują się jako głęboko wierzące, a nie uczestniczą w praktykach religijnych $(10 \%)^{42}$.

Kolejną nowością, którą ukazują badania, jest fakt spadku religijności dziewcząt. One zawsze odznaczały się większą gorliwością zarówno w autodeklaracji wiary, jaki i w praktykach. Obecnie brak zaangażowania w praktyki religijne deklaruje 28\% dziewcząt, w 2013 roku było to $19 \%{ }^{43}$.

Pewne zmiany religijności zachodzą również w przypadku młodzieży mieszkającej w większych miastach i na wsi. Otóż młodzi z większych aglomeracji częściej określają się jako niewierzący, natomiast młodzież żyjąca na wsi coraz częściej zaniedbuje praktyki religijne. W ciągu ostatnich trzech lat odsetek osób nigdy w nich nieuczestniczących wzrósł na wsi z $17 \%$ do $24 \%{ }^{44}$.

Obecnie na lekcje religii uczęszcza $75 \%$ uczniów ostatnich klas ponadgimnazjalnych. To niemało, choć poziom ten jest niższy niż w roku 2013 (89\%), różnica wynosi więc 14 punktów procentowych. Największy spadek odsetka uczniów uczestniczących w lekcjach religii odnotowano w liceach ogólnokształcących - 17 punktów procentowych w stosunku do 2013 roku. Lepsza sytuacja jest w technikach, gdzie spadek ten wynosi 13 punktów procentowych. Poziom uczestnictwa w lekcjach religii ściśle wiąże się z miejscem zamieszkania. Młodzi mieszkający na wsi chodzą na religię niemal powszechnie (85\%). Współczynnik ten obni-

\footnotetext{
41 Mariański, „Kondycja religijna”, 148.

42 Głowacki, „Religijność młodzieży”, 143-153.

43 Głowacki, „Religijność młodzieży”, 143-153.

44 Głowacki, „Religijność młodzieży”, 143-153.
} 
ża się natomiast wraz z wielkością miasta, osiągając wartość poniżej $50 \%$ w największych ośrodkach. Dwie piąte młodzieży (40\%) uważa, że lekcje religii są ciekawe i deklaruje, że chodzi na nie z ochotą. Opinie krytyczne - że lekcje religii są nudne i nic ważnego się na nich nie dzieje - podziela co piąty uczeń (22\%). Pozostali (38\%) uważają, że lekcje religii niczym się nie wyróżniają - „są jak każda inna lekcja” ${ }^{45}$.

Omawiając religijność młodego pokolenia Polaków, warto wziąć pod uwagę jeszcze jedno zjawisko. Dotyczy ono rodziców. Zmniejsza się bowiem odsetek młodzieży deklarującej, że rodzice wymagają od nich chodzenia do kościoła. Zmiany na tym polu są poważne. W porównaniu z rokiem 2013 wyniosły one 9 , z rokiem 2008 - 19, a z 1998 - aż 22 punkty procentowe ${ }^{46}$. W kwestiach wiary coś się zatem zmienia nie tylko u młodych ludzi, lecz także w ich domach. Być może zmieniają się postawy i poglądy rodziców albo rodzice stawiają coraz mniejsze wymagania w kwestii wiary wobec swoich dzieci.

Spadek deklarowanych wierzeń i praktyk religijnych oraz akceptacji norm moralnych katolicyzmu pozwala przypuszczać, że religia odgrywa słabnącą rolę w życiu codziennym młodych Polaków ${ }^{47}$.

\section{RODZINA I SZKOŁA W OPINII MŁODZIEŻY}

Rodzina ponownie staje się bardzo ważnym środowiskiem dla młodych ludzi. Można pokusić się o stwierdzenie, że po okresie odwrotu od rodziny następuje teraz powrót do rodzinnych wartości.

Zdecydowana większość badanych uczniów mieszka z obojgiem rodziców (75\%), w rodzinach niepełnych wychowuje się $18 \%$ młodych ludzi, przy czym prawie wszyscy

\footnotetext{
45 Gwiazda, „Religia w szkole”, 154-160.

46 Gwiazda, „Religia w szkole”, 154-160.

47 Mariański, „Kondycja religijna”, 149.
} 
z nich mieszkają jedynie z matką (15\%), a z ojcem tylko $3 \%$. Nieliczni uczniowie mieszkają z kimś z dalszej rodziny, np. $\mathrm{z}$ babcią (2\%). W ostatnich latach maleje odsetek uczniów wychowujących się z obojgiem rodziców. W 2003 roku młodzi ludzie mający pełną rodzinę stanowili 82\%, a w 2016 już tylko $75 \%{ }^{48}$.

Sytuacja rodzinna wiąże się także z religijnością uczniów. Mieszkanie z obojgiem rodziców sprzyja regularnym praktykom religijnym.

Jednym $\mathrm{z}$ istotnych zjawisk społecznych mających wpływ na sytuację rodzinną i wychowawczą dzieci i młodzieży w Polsce jest migracja zarobkowa. Ogółem więcej niż co szósty ankietowany (17\%) miał osobiste doświadczenie związane $\mathrm{z}$ wyjazdem zarobkowym za granicę przynajmniej jednego $\mathrm{z}$ rodziców ${ }^{49}$. $\mathrm{Z}$ reguły do pracy za granicą wyjeżdżają ojcowie, rzadziej matki.

Dom jest miejscem, gdzie szuka się bezpieczeństwa, oparcia, autorytetu. Grupa rówieśnicza kształtuje wzory zachowania, stylu bycia, sposoby spędzania wolnego czasu, jest miejscem rozwijania zainteresowań. Opinie te znajdowały potwierdzenie w dotychczasowych wynikach badan, obecnie zaś przestają być już takie oczywiste. Ostatnie analizy pokazują z jednej strony spadek roli grupy rówieśniczej w życiu młodych ludzi, z drugiej zaś - wzrost znaczenia rodziców jako autorytetów. Rówieśnicy nie tylko rzadziej niż w latach ubiegłych pełnią rolę autorytetów, lecz także rzadziej należą do grona osób, z którymi młodzi ludzie chętnie spędzają wolny czas.

Autorytetami dla młodzieży, a więc osobami, o które uczniowie zabiegają, są najczęściej rodzice. Matka ma tu miejsce szczególne. 59\% młodzieży uważa matkę za autorytet, nieco rzadziej (47\%) - ojca. Zdecydowanie rzadziej tę rolę pełnią rodzeństwo i znajomi. Również matka jest dla młodych lu-

48 Roguska, „Dom rodzinny”, 19-28.

49 Roguska, „Dom rodzinny”, 19-28. 
dzi przede wszystkim źródłem wsparcia (60\%). Po pomoc w trudnych chwilach $29 \%$ ankietowanych zwróciłoby się do ojca. Porównywalnie często jak do ojca uczniowie wymieniali w tym kontekście przyjaciół (34\%) oraz chłopaka lub dziewczynę $(27 \%)^{50}$.

Obok rodziny ważną funkcję w procesie wychowawczym pełni szkoła. Pytając młodych ludzi o klimat w niej panujący, można stwierdzić, że z tym bywa różnie. Często zależy to od typu szkoły i miejscowości. Jednak większość uczniów ma nauczycieli, których ceni i lubi. Oczywiście, że szkoła jest częściej miejscem stresu niż satysfakcji, jednak ostatnie badania pokazują, że uczniowie coraz częściej czują się doceniani i więcej czerpią satysfakcji z edukacji ${ }^{51}$.

\section{STOSUNEK DO POLITYKI I ŻYCIA SPOŁECZNEGO}

Młode pokolenie nazywane jest często młodością bez skrzydeł. Milenialsi nie mają wielkich ideałów. Nie pociągają ich wzniosłe wartości przebudowy świata, nie dążą do ustanowienia innego lepszego ustroju społecznego. Młodzież lat dziewięćdziesiątych tworzyła organizacje pozarządowe, podejmowała działania społeczne w trzecim sektorze. Młodzież przełomu i początku XXI wieku to generacja, która koncentruje się na własnej przyszłości.

Mają słabo zakorzenione w świadomości znaczenie społeczeństwa obywatelskiego. Odpowiedzialność za innych i wejście w sferę społeczną nie są postrzegane jako wartość. W przeciwieństwie do swoich rówieśników z poprzednich dekad późno dojrzewają społecznie i nie są zainteresowani światem dorosłych ${ }^{52}$.

Młodzież kończąca edukację w szkołach ponadgimnazjalnych określa swoje zainteresowanie polityką jako śred-

\footnotetext{
50 Pawlina, Mtodzi w parafii, 42-44.

51 Kałka, „Szkolne relacje”, 39-60.

52 Kaźmierska, Mtodzież archidiecezji tódzkiej, 54.
} 
nie. 36\% badanych śledzi jedynie najważniejsze wydarzenia polityczne. Zdecydowaną mniejszość nadal stanowią uczniowie twierdzący, że uważnie obserwują scenę polityczną (17\%). W porównaniu z 2013 rokiem jest to wzrost o 6 punktów procentowych. Mimo zmniejszenia się grupy deklarujących, że polityka praktycznie ich nie interesuje, to stanowią oni niemal jedną czwartą ogółu badanych (23\%). Zmieniają się też deklaracje dotyczące poglądów politycznych. O ile w 2013 roku blisko trzy czwarte (72\%) uczniów ostatnich klas szkół ponadgimnazjalnych nie potrafiło sprecyzować swoich poglądów politycznych, to obecnie dotyczy to mniej niż dwóch trzecich (64\%). Od 2013 roku zwiększyła się grupa badanych deklarujących prawicowe poglądy polityczne (z 14\% do 20\%). Obecnie jest ich niemal tyle samo, co w roku $1996^{53}$.

\section{STOSUNEK Do PRACY}

O ile baby boomers żyją, żeby pracować, a generacja X szuka równowagi między pracą a życiem, o tyle milenialsi po prostu pracują, żeby żyć. Nie jest niczym niespotykanym, że milenials popracuje rok, a potem przez kolejny będzie się wspinał w Himalajach lub wyruszy na poszukiwanie innych przygód ${ }^{54}$.

Nie są pracusiami, ale chcą zarabiać. Praca musi być dla nich satysfakcjonująca. Nie wystarcza, że jest dochodowa. Milenialsów się nie zatrudnia, z milenialsami się współpracuje. Chcąc mieć w nich pracownika, trzeba się dostosować do ich wymagań, np. poprzez indywidualne ułożenie grafiku pracy. Wymagają oni innego podejścia - bardziej elastycznego ${ }^{55}$.

\footnotetext{
53 Badora - Herrman, „Młodzież o polityce”, 91-130.

54 Espinoza Ukleja, Zarządzanie milenialsami, 40.

55 Szczypczyk, „Cała prawda o Milenialsach”.
} 
Sami o sobie mówią tak: „Praca nas nie definiuje, chcemy decydować o tym, kiedy pracujemy i jak wykonujemy swoją

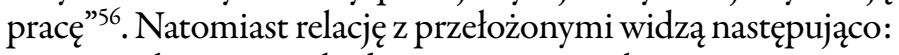
„Nie oczekujemy, że będziesz naszym najlepszym przyjacielem, ale kiedy nas oceniasz lub krytykujesz, chcemy, byś robił to przyjaźnie (tak jak robili to rodzice milenialsów), chcemy, żebyś wyznaczył kierunek, a potem zszedł nam z drogi” ${ }^{2}$.

Milenialsi mają wysokie mniemanie o sobie. Uważają, że pracują lepiej i szybciej niż inni pracownicy. Chcą, żeby menadżerowie angażowali się w ich rozwój zawodowy, ponieważ chodzi im o nich, a nie tylko o firmę. Chcą być dostrzegani i doceniani już pierwszego dnia w nowej pracy ${ }^{58}$.

$\mathrm{Z}$ drugiej zaś strony, zjawiskiem zgłaszanym przez pracodawców jest brak lojalności milenialsów wobec zakładu pracy ${ }^{59}$. Ponadto przełożeni charakteryzują ich tak: „Jeśli ich poprawisz, odchodzą; chcą nagrody za samo pojawienie się w pracy; sądzą, że zawsze istnieje wymówka sprawiająca, że spóźnianie się będzie w porządku; zakładają, że mogą mi mówić po imieniu, jakbyśmy byli kumplami, a jestem ich szefem; kiedy zrobię dla nich ekstra coś miłego, zachowują się tak, jakby im się to po prostu należało"60.

Bez wątpienia nigdy wcześniej młodzi ludzie nie byli tak niezależni od osób zajmujących w danej dziedzinie wysokie stanowiska. Internet niejako wyrównał szanse młodych osób, które próbują zbudować swoją karierę. Jakże dużo w sieci młodych samodzielnych przedsiębiorców wytwarzających produkcje YouTube zamiast produkcji studyjnych, blogi zamiast gazet, aplikacje zamiast całych gałęzi biznesu ${ }^{61}$.

W ostatnich trzech latach wyraźnie zmieniło się podejście młodzieży do rynku pracy i oceny własnych szans zawo-

\footnotetext{
56 Espinoza Ukleja, Zarządzanie milenialsami, 42.

57 Espinoza Ukleja, Zarządzanie milenialsami, 42.

58 Espinoza Ukleja, Zarządzanie milenialsami, 42-43.

59 Pawińska, Millennialsi, 218.

60 Espinoza Ukleja, Zarządzanie milenialsami, 41-42.

61 Pawińska, Millennialsi, 219.
} 
dowych. Ponad połowa badanych (52\%) uważa, że obecnie najważniejsze w poszukiwaniu pracy są inteligencja i zdolności. Nieco mniejsze znaczenie w tym względzie przypisują posiadaniu znajomości i układów. Ważna, zdaniem młodych, jest też znajomość języków obcych (48\%). Kolejnym istotnym czynnikiem w poszukiwaniu pracy jest wyuczenie zawodu (45\%). Znacznie niżej w hierarchii czynników decydujących o znalezieniu pracy plasują się odwaga i przedsiębiorczość (25\%) oraz szczęście i przypadek $(14 \%)^{62}$.

\section{ZAINTERESOWANIA I AKTYWNOŚCI MEODZIEŻY}

Młodzież ceni sobie czas wolny. Najwięcej tego czasu spędza na spotkaniach z przyjaciółmi i znajomymi (85\%). Sporą jego część przeznacza też na aktywność rozrywkową, głównie na wyjście do dyskoteki czy klubu (22\%). Jednak w ostatnich trzech latach miłośników tego typu rozrywek ubyło. Ponad jedna trzecia badanych (35\%) najchętniej przeznacza wolny czas na uprawianie sportu. Około jedna czwarta uczniów lubi spędzać czas na grach komputerowych $(26 \%)$ i na serfowaniu w Internecie $(23 \%)^{63}$.

Jeśli chodzi o przynależność młodzieży do grup, stowarzyszeń i organizacji, można stwierdzić, że odsetek ten jest względnie stabilny w ostatnich kilku latach (33\%). Najwięcej uczniów należy do różnych organizacji, związków oraz stowarzyszeń sportowych i klubów kibica (17\%). Na drugim miejscu plasują się kluby kulturalne i hobbystyczne (9\%). Trzecie miejsce zajmują organizacje i stowarzyszenia związane z działalnością społeczną (6\%). W porównaniu z poprzednią dekadą mniejsza jest skala członkostwa w organizacjach i stowarzyszeniach religijnych, deklaruje je obecnie $5 \%$ badanych $^{64}$.

\footnotetext{
62 Boguszewski, „Aspiracje”, 65-87.

63 Feliksiak, „Zainteresowania i aktywność”, 186-189.

64 Feliksiak, „Zainteresowania i aktywność”, 178-190.
} 


\section{Podziurawiona mentalność}

Badania socjologiczne pokazują, że milenialsi deklarują pragnienie stabilności, posiadania szczęśliwej rodziny i trwałej pracy. To mogłoby napawać optymizmem, gdyby nie fakt, że ci sami młodzi ludzie nie potrafią stabilności zbudować. Oczekują od pracodawcy przeróżnych gwarancji i zabezpieczeń, a z drugiej zaś strony sami nie mają skrupułów, żeby zwolnić się z dnia na dzień, gdy im coś nie odpowiada. Przyczyn stosunkowo częstych zmian miejsca pracy można upatrywać $\mathrm{w}$ tym, że milenialsi, w porównaniu do wcześniejszych pokoleń, mają jednak mniejszą potrzebę bezpieczeństwa i stabilizacji, a większą wolności i autonomii, stąd nie zmierzają do ustatkowania się w jednym miejscu na dłużej niż kilka lat ${ }^{65}$. Cecha ta dotyczy również takich aspektów jak miejsce zamieszkania czy podejmowanie kluczowych decyzji życiowych, na przykład kredyt na mieszkanie czy małżeństwo.

W tej ostatniej kwestii, to pragną oni szczęśliwej rodziny, odwzajemnionej miłości, a sami przy najmniejszym rozczarowaniu porzucają i odchodzą. Pokolenie, które nie reperuje, lecz wyrzuca i wymienia na nowe. Wskazuje to przynajmniej na dwie sprawy. Pierwsza to niewiarygodność deklaracji młodych ludzi. Druga to roszczeniowa postawa wobec innych, przy jednoczesnym braku własnej odpowiedzialności za decyzje i zobowiązania.

\section{WNIOSKI PASTORALNE}

Interdyscyplinarność teologii pastoralnej zakłada współpracę z naukami pozateologicznymi, w szczególności z socjologią i psychologią religii, co pozwala konstruować wnioski dla pozostałych dyscyplin kościelnych. Dynamicznie za- 
chodzące przemiany kulturowo-społeczne uniemożliwiają jednak wypracowanie długotrwałych modeli teologicznych i programów działania. Większą rolę odgrywa proces nieustannej refleksji pastoralnej, która buduje nowoczesne duszpasterstwo, z jednej strony na podstawie wskazań ewangelicznych, z drugiej zaś dzięki zrozumieniu sytuacji współczesnego człowieka.

Częste wypowiedzi papieża Franciszka z ostatnich lat przekonywały duszpasterzy, że konieczne jest dotarcie do młodego człowieka i umożliwienie mu wypowiedzi bez pośrednictwa i „przefiltrowania” ich poglądów ${ }^{66}$. Dlatego dokument końcowy Synodu Biskupów Mtodzi, wiara i rozeznawanie powotania kładzie duży nacisk na umiejętność towarzyszenia młodym ludziom w rozeznawaniu ich życiowej drogi. Obecna do tej pory tendencja do priorytetowego traktowania programów i struktur eklezjalnych okazała się niedostatecznym sposobem ewangelizowania nastolatków. „Nie wystarczy posiadanie struktur, jeśli nie rozwijają się w nich autentyczne relacje; to właśnie jakość takich relacji ewangelizuje" ${ }^{67}$. Relacje rodzą się podczas empatycznego wysłuchiwania rozmówcy. Wiele środowisk akademickich w Polsce zgłasza na pierwszym miejscu postulat towarzyszącej obecności, rozmowy i indywidualnego kierownictwa. Na kolejnym miejscu wymienia się potrzebę wspólnoty i budowania relacji, kształtowania człowieczeństwa, a dopiero potem formacji intelektualnej. Wśród młodych rośnie powoli także tendencja przynależności do grup tradycjonalistycznych.

Posługa biskupów i kapłanów jest obciążona licznymi obowiązkami, jak przyznaje Synod, ale konieczne jest uwzględnienie w tej posłudze słuchania młodzieży jako podstawowego elementu towarzyszenia $w$ dorastaniu ${ }^{68}$. Jest to charyzmat Ducha Świętego, którego nie można pominąć w duszpasterstwie.

\footnotetext{
66 Franciszek, Przemówienie.

67 Synod Biskupów, Mtodzi, 47.

68 Synod Biskupów, Mtodzi, 8.
} 
Przedstawione w obecnym artykule wyniki badań socjologicznych polskiej młodzieży są punktem wyjścia do zrozumienia sytuacji tej grupy społecznej. Są początkiem słuchania młodego człowieka i refleksją nad drogami współczesnego wychowania. Wynikające z badań zróżnicowanie poglądów i aspiracji ludzkich nie musi okazać się przeszkodą, ale szansą w budowaniu harmonijnego społeczeństwa, rodząc „symfoniczne bogactwo" ${ }^{69}$. Rolą tych duszpasterzy, którzy pragną ewangelizować wśród młodzieży, jest więc zrozumienie sytuacji młodych ludzi i różnorodności ich przekonań.

\section{BIBLIOGRAFIA}

Badora b. - Herrmann m., „Młodzież o polityce, demokracji i gospodarce", Mtodzież 2016 (red. M. Grabowska M. Gwiazda) (Opinie i Diagnozy 38; Warszawa: CBOS 2017) 91-130.

Boguszewski R., „Aspiracje, dążenia i plany życiowe młodzieży”, Mtodzież 2016 (red. M. Grabowska - M. Gwiazda) (Opinie i Diagnozy 38; Warszawa: CBOS 2017) 65-87. Boguszewski R., „Dobroczynność w Polsce”, Komunikat CBOS nr 40 (2016).

Boguszewski R., „Religijność Polaków i ocena sytuacji Kościoła katolickiego", Komunikat CBOS nr 147 (2018).

Boni M. - Szafraniec K., Mtodzi 2011 (Warszawa: Kancelaria Prezesa Rady Ministrów 2011).

Czerski P., „My, dzieci sieci”, Dziennik Battycki 35/20452 (2012) 11.

Espinoza C. - Ukleja M., Zarządzanie milenialsami (Warszawa: Wydawnictwo Naukowe PWN 2018).

Feliksiak M., „Zainteresowania i aktywność”, Mtodzież 2016 (red. M. Grabowska - M. Gwiazda) (Opinie i Diagnozy 38; Warszawa: CBOS 2017) 186-189.

69 Synod Biskupów, Mtodzi, 48 . 
Flader M., „Wiara w czasach portali społecznościowych. Charakterystyka pokolenia sieciowego", Duszpasterstwo mtodzieży w Polsce wobec wspótczesnych przemian (red. P. Ochotny - M.J. Tutak - T. Wielebski) (Teologia Pastoralna w Polsce 5; Warszawa: Wydawnictwo i Księgarnia „Gotów” Katolickiego Stowarzyszenia Młodzieży 2018) 433-452.

Głowacki A., „Religijność młodzieży”, Mtodzież 2016 (red. M. Grabowska - M. Gwiazda) (Opinie i Diagnozy 38; Warszawa: CBOS 2017) 143-153.

Gwiazda M., „Religia w szkole - uczestnictwo i ocena”, Mtodzież 2016 (red. M. Grabowska - M. Gwiazda) (Opinie i Diagnozy 38; Warszawa: CBOS 2017) 154-160.

Kałka J., „Szkolne relacje”, Mtodzież 2016 (red. M. Grabowska, M. Gwiazda) (Opinie i Diagnozy 38; Warszawa: CBOS 2017) 39-60.

Kaźmierska K., Mtodzież archidiecezji tódzkiej. Szkic do portretu (Łódź: Archidiecezjalne Wydawnictwo Łódzkie 2018). Mariański J., „Kondycja religijna i moralna młodzieży szkół średnich", Duszpasterstwo mtodzieży w Polsce wobec wspótczesnych przemian (red. P. Ochotny - M.J. Tutak T. Wielebski) (Teologia Pastoralna w Polsce 5; Warszawa: Wydawnictwo i Księgarnia „Gotów” Katolickiego Stowarzyszenia Młodzieży 2018) 141-150.

Nastolatki 3.0. Raport z badania (Warszawa: NASK - Instytut Badawczy 2017).

Pawińska M., „Millennialsi - inspiratorzy nieuchronnych zmian w środowisku akademickim w Polsce i na świecie", Ogrody Nauk i Sztuk 8 (2018) 215-223.

Pawlina K., Co stychać u mtodzieży (Warszawa: Wydawnictwo Sióstr Loretanek 2019).

Pawlina K., Mtodzież szkolna o swoich problemach (Warszawa: Wydawnictwo Sióstr Loretanek 2010).

Pawlina K., Mtodzi w parafii. Problemy i wyzwania (Warszawa: Wydawnictwo Sióstr Loretanek 2015). 
Roguska B., „Dom rodzinny, rodzice i rówieśnicy w opiniach młodego pokolenia Polaków", Mtodzież 2016 (red.

M. Grabowska - M. Gwiazda) (Opinie i Diagnozy 38:

Warszawa: CBOS 2017) 19-28.

Stańczak J. - Stelmach K. - Urbanowicz M., Matżeństwa oraz dzietność w Polsce (Warszawa: GUS 2016).

Szawiel T., Pokolenie JP2. Przysztość i przesztośćzjawiska religijnego (Warszawa: Wydawnictwo Naukowe Scholar 2008).

Tomczuk J., „Pokolenie «lap szansę»”, Newsweek Polska nr 20 (2018) 32-35.

Netografia

XV Zgromadzenie Ogólne Synodu Biskupów, Mtodzi, wiara $i$ rozeznawanie powotania. Dokument końcowy (2018), https://episkopat.pl/dokument-koncowy-synodu-biskupow-mlodzi-uczestnikami-i-wspoltworcami-zgromadzenia/ (dostęp: 6.04.2019)

SIA, „Czapiński w TOK FM: Mentalność, igreków’ jest kształtowana przez memy, a nie mamy", 9.05.2012, http:// wiadomosci.gazeta.pl/wiadomosci/1,114873,11692545, Czapinski_w_TOK_FM_Mentalnosc_igrekow_jest_ ksztaltowana.html (dostęp: 28.02.2019).

Franciszek, Przemówienie do mtodzieży w Santiago, 17.01.2018, https://opoka.org.pl/biblioteka/W/WP/franciszek_i/ przemowienia/chile-mlodziez_17012018.html (dostęp: 23.03.2019)

Moczyróg A., „Było pokolenie Y, teraz czas na 'pokolenie Homeland'. Oto, na kogo wyrosną Twoje dzieci”, 03.09.2015, https://mamadu.pl/121227, jakie-pokolenie-przyjdzie-po-milenialsach-czyli-na-kogo-wyrosna-nasze-dzieci (dostęp: 28.02.2019).

Polityka.pl, „Milenialsi, generacja Z... Skąd wiadomo, do którego pokolenia się należy?", 19.03.2016, https://www. polityka.pl/tygodnikpolityka/ludzieistyle/1654918,1,mil 
enialsi-generacja-z-skad-wiadomo-do-ktorego-pokolenia-sie-nalezy.read (dostęp: 28.02.2019)

Stańczak J. - Stelmach K. - Urbanowicz M., Matżeństwa i dzietność w Polsce, I 2016,

https://stat.gov.pl/obszary-tematyczne/ludnosc/ludnosc/ malzenstwa-i-dzietnosc-w-polsce,23,1.html (dostęp: 6.04.2019)

Szczypczyk K., „Cała prawda o Milenialsach”, 28.07.2017, http://konradszczypczyk.pl/cala-prawda-o-millenialsach/ (dostęp: 28.02.2019)

Ks. Krzysztof Pawlina, prezbiter archidiecezji warszawskiej, profesor nauk teologicznych, rektor Papieskiego Wydziału Teologicznego w Warszawie, przewodniczący Kolegium Dziekanów Wydziałów Teologicznych w Polsce, sekretarz Rady Naukowej Konferencji Episkopatu Polski, przewodniczący Warszawskiego Towarzystwa Teologicznego, członek Komisji Episkopatu ds. Duchowieństwa, dziekan Kapituły Metropolitalnej Warszawskiej, w latach 1997-2010 rektor Wyższego Seminarium Duchownego w Warszawie. W swojej pracy naukowej zajmuje się trzema dziedzinami: młodzieżą, nową ewangelizacją i kapłaństwem. Jest autorem wielu publikacji naukowych i popularnonaukowych, książek, w tym dla młodzieży i o młodzieży, a także kilku tomików poezji. 
